\title{
'Voices' from the UNTAC files: policy and politics of accommodation in Phnom Penh after the Khmer Rouge
}

\author{
Thomas Kolnberger
}

\begin{abstract}
During the 1980s, refugee camps along the Thai-Cambodian border constituted the power base for the civil war parties opposing the People's Republic of Kampuchea (PRK, 1979-91). Politics of accommodation and basic services also played a key role in the 'original accumulation' of political power by the new regime in Phnom Penh. The resettlement process of Cambodia's deserted cities developed into a major playground for clientelism, the foundation of Cambodia's state-building process after the Khmer Rouge. Focusing on the archival heritage of the United Nations Transitional Authority in Cambodia (UNTAC) 1992-93, a spatial analysis of Phnom Penh's political geography from the late 1970s to the late 1990s will be provided. This paper argues that the UNTAC time marked a watershed, whose impact has been underrated for Cambodia's political future: the transition in the accommodation policy of a besieged regime. UNTAC did not end the civil war, but changed the political economy of the country. As the need to 'camp-in' and share billeted living space gradually diminished, the socialist 'moral economy' mutated into quick money politics and political family business to ensure the hegemonic status of Cambodia's ruling party further.
\end{abstract}

Keywords: historical geography; re-urbanization; clientelism; Cambodia 1970s1990s; Phnom Penh; UNTAC

Author details: Dr Thomas Kolnberger is with the Department of History (Research Unit IPSE), Université du Luxembourg, Campus Belval, Maison des Sciences Humaines, 11 Porte des Sciences, L-4366 Esch-sur-Alzette, Luxembourg. E-mail: thomas.kolnberger@gmx.at.

Twice within a few years, the city of Phnom Penh morphed into an urban refugee camp. Due to war-related migration, Cambodia and its capital witnessed extreme demographic changes in the late 1970s. As a 'sideshow', ${ }^{1}$ the Kingdom of Cambodia $^{2}$ had gradually become involved in the Vietnam War. ${ }^{3}$ Waves of migration swept into the country's cities from the combat zones and from the target areas of

\footnotetext{
William Shawcross (1979), Sideshow: Nixon, Kissinger, and the Destruction of Cambodia, Simon and Schuster, New York.

After the coup against Prince and Head of State Norodom Sihanouk in March 1970, Cambodia became a republic (Khmer Republic, monarchy abolished by the 1972 Constitution) headed by President Lon Nol until April 1974; see: Justin J. Corfield (1994), Khmers Stand Up! - A History of the Cambodian Government 1970-1975, Centre of Southeast Asian Studies, Monash University, Melbourne.

Second Indochina War (1955-1975). Saigon, the capital of the Republic of Vietnam (1955-75), was taken by North Vietnamese troops and 'Vietcong' on 30 April 1975, two weeks after the fall of Phnom Penh.
}

South East Asia Research, 23, 3, pp 377-404 doi: 10.5367/sear.2015.0268 
US carpet bombings ${ }^{4}$ along the borders to Laos and South Vietnam. When the advancing Khmer Rouge fighters finally closed their military encirclement of Phnom Penh, over two million people - more than twice the peacetime population - were trapped in the pocket. Immediately after the victorious entry on 17 April 1974, the revolutionary leadership launched its most radical reform: the forced 'ruralization' (or de-urbanization) of Phnom Penh's resident population and the 'repatriation' of the war refugees to the countryside.

After severe border skirmishes and the complete political break with Hanoi, Vietnamese troops launched an invasion against the Pol Pot regime, liberated Phnom Penh in a swift military operation, and occupied most of Cambodia during the monsoon dry season in the winter of 1978/79 within a matter of weeks. The Khmer Rouge rounded up the population under its control and withdrew. ${ }^{5}$ Cambodia/ Kampuchea became a protectorate of Vietnam, ${ }^{6}$ while the Khmer Rouge reversed its tactics and became a guerrilla force again: first in Cambodian territory and later, edged out by the so-called K5 Plan and military offensive of Vietnamese and PRK troops (1985-89) ${ }^{7}$ beyond the border within refugee camps in Thailand. This bipolar geography of local power and international spheres of influence persisted until the Paris Peace Agreements of 1991 and the closure of the border refugee camps.

What did happen to Phnom Penh after the Khmer Rouge retreated in 1979 is a question this paper will address, analysing the evolution of the spatial order from a camp-like urban situation to an open city. On the micro and macro levels, the origins of Cambodia's current socio-political realities can be identified.

Conservative leaders of the Vietnamese-sponsored Communist Party of the PRK were initially reluctant to accept the immediate repopulation of the towns. The official recognition of the re-urbanization was granted by the Council of Ministers only in $1984 .{ }^{8}$ The process could not be stopped, and the capital's population increased exponentially from several thousands in 1979 to about half a million in 1988 (see Appendix). In that year, Uk Bunchheaun, a former Khmer Rouge defector and PRK Minister of Justice, commented in the minutes of the Council of Ministers, 'We are in a war of houses and a war of land'. ${ }^{9}$ This 'war', however,

4 Later on, the bombing campaigns targeted the whole north-eastern part of Cambodia - the total tonnage of ordnance was the largest since the Second World War. One objective of the US Air Force was to halt the advance of the Khmer Rouge; see Owen Taylor and Ben Kiernan (2006), 'Bombs over Cambodia', The Walrus, October, pp 62-69.

5 Around 300,000 were forcefully displaced during the retreat, according to Nayan Chanda (1986), Brother Enemy: The War after the War, Harcourt Brace Jovanovich, San Diego, New York and London, pp 370.

6 The way scholars, journalists, politicians or witnesses portray the Vietnamese intervention oscillates between (brutal) occupation and (gratefully accepted) liberation: for example, see Stephen R. Heder (1980), Kampuchean Occupation and Resistance, Asian Studies Monographs No 27, Chulalongkorn University, Bangkok; Marie-Alexandrine Martin (1994), Cambodia: A Shattered Society, University of California Press, Los Angeles, CA, and London, p 215; Michael Vickery (1984), Cambodia: 1975-1982, South End Press, Boston, MA, pp 189-252.

7 Margaret Slocomb (2001), 'The K5 gamble: national defence and nation building under the People's Republic of Kampuchea', Journal of Southeast Asian Studies, Vol 32, No 2, pp 195-210; Margaret Slocomb (2002), The People's Republic of Kampuchea, 1979-1989 - The Revolution after Pol Pot, Silkworm Books, Chiang Mai, pp 229-251; Esmeralda Luciolli (1988), Le Mur de Bambou - Le Cambodge après Pol Pot, Régine Deforges, Paris.

8 Evan Gottesman (2002), Cambodia after the Khmer Rouge - Inside the Politics of Nation Building, Yale UP, New Haven and London, p 200.

$9 \quad$ Ibid, p 320. 
reached fever pitch during the years of the United Nations Transitional Authority in Cambodia (UNTAC). In Phnom Penh, against the background of the civil war, the PRK government became sovereign in the state of emergency by the political economy of accommodation.

\section{The UNTAC period reconsidered: aims and approaches of the paper}

Embedded in the geopolitics of the Cold War, socio-topographical conditions have influenced Cambodia's political geography and future decisively. Little research has focused on this, particularly as a close-up on the re-urbanization of Cambodia. Evan Gottesman probably gives the most detailed account of Phnom Penh after the Khmer Rouge, but does not discuss the relationship between politics and urban space from a geographical perspective. His primary interest and time frame are the years before UNTAC. Other researchers highlight the transitional period of UNTAC and its aftermath. ${ }^{10}$ In this respect, this paper offers a further study of the issues that deal with the 'bigger picture' of Cambodia before and after Khmer Rouge rule (1975-79). The focus is on the transitional period, when UNTAC (199293) sought to control the capital. The theme is examined from four different angles: first, 'from below', by looking at the neo-inhabitants of Phnom Penh; second, by analysing spatially how Phnom Penh was resettled at a micro level; third, by seeing how the politics of accommodation worked in situ; and finally, the paper will assess the impact of the late PRK regimes in easing measures on the economy and of the transitional period on the real estate situation. In doing so, the paper explores the voluminous archival heritage of the UN Authority: the so-called UNTAC files kept by the National Archives of Cambodia in Phnom Penh (NAC).

As a general framework to interpret these recently disclosed sources spatially, I refer in particular to Adeline Carrier's pioneering study, which examines the period leading up to that of UNTAC.

In her thesis, Carrier scrutinizes the principles of the People's Republic of Kampuchea (1979-91), guiding the reappropriation of Phnom Penh's real estate as the new Khmer-Vietnamese government took over the capital at the end of 1978. ${ }^{11}$ Carrier systematically unfolds the modus of real estate allocation, its hierarchy and the rule of order by PRK law and informal practice. She also discerns growing contradictions between socialist policies set up in the initial years of the People's Republic, and the creeping transition of political and daily practice into that of the 'market economy' towards the end of its rule. In 1993, the constitution of the restored kingdom included an article for the adoption of a market economy system. ${ }^{12}$ In part, this economic transition was already under way before the arrival

10 Slocomb, supra note 7; Caroline Hughes (2003), The Political Economy of Cambodia's Transition, 1991-2001, Routledge-Curzon, London and New York; David W. Roberts (2001), Political Transition in Cambodia 1991-99 - Power, Elitism and Democracy, Curzon, Richmond; Simon Springer (2010), Cambodia's Neoliberal Order - Violence, Authoritarianism, and the Contestation of Public Space, Routledge, London and New York.

11 Adeline Carrier (2007), 'Les "lois de la possession" à Phnom Penh: conversion des droits d'usage résidentiel issus du contexte socialiste de réappropriation urbaine (1979-1989) en droits de propriété', PhD dissertation, University of Paris VIII.

12 Constitution adopted by the Constitutional Assembly in Phnom Penh on 21 September 1993, Chapter V, Article 56; cf Raoul M. Jennar (1994), Les constitutions du Cambodge: 1953-1993 (Textes rassemblés et présentes par R.M. Jennar), La Documentation Française, Paris. 
of UNTAC when more pragmatically oriented groups of the PRK leadership gained the political upper hand over communist hardliners. ${ }^{13}$ The 'top-down', legalistic and socio-urbanistic approach of Carrier will be extended here by a 'bottom-up' perspective, analysing 'voices' from the UNTAC files, completed by investigative interviews conducted during the research period in Cambodia in the winter of 2011-12.

\section{The 'original accumulation' of political power in Phnom Penh after the fall of the Khmer Rouge}

'Original accumulation' ${ }^{14}$ in its initial Marxist sense, concerns the historical origins of real capital ${ }^{15}$ and how 'class distinction' ('Klassenunterschiede') came to be. ${ }^{16}$ That is a vital question for the establishment of a new order in Cambodia after Pol Pot's reign of terror. In Cambodia, where land was abundant, only city space was a scarce commodity. The real estate and housing sector of Phnom Penh remained - just as in any economy above the level of subsistence living - a field of political interventions of all sorts. ${ }^{17}$

While the open conflict of the civil war lasted,${ }^{18}$ the whole country was divided along suspicious and violent lines of first two, then four political camps in two coalition blocs. This situation materialized in a fragmented regional topography. The necessity for the government of the PRK to 'engineer' loyalty to counterbalance its opponents along the border turned Phnom Penh virtually into a camp, which hence became a place for the 'original accumulation' of political and economic power.

13 After the withdrawal of the Vietnamese forces, the second PRK constitution of 1989, replacing the one of 1981 (which was modelled on the Vietnamese) ended the socialist economy, especially the collectivization policy and collective farming; see Viviane Frings (1993), The Failure of Agricultural Collectivization in the People's Republic of Kampuchea (1979-1989), Working Paper 80, Center of Southeast Asian Studies, Monash University, Melbourne; Viviane Frings (1994), 'Cambodia after decollectivization (1989-1992)', Journal of Contemporary Asia, Vol 24, No 1 , pp 49-66. Additionally, for the real estate sector, see Valérie Clerc and Virginie Rachmuhl (2008), Les marchés fonciers et immobiliers des quartiers informels à Phnom Penh, Éditions du Gret, Paris, pp 37-69; East-West Management Institute (2003), Land Law of Cambodia - A Study and Research Manual, prepared by the East-West Management Institute, Phnom Penh.

14 Karl Marx (1973), 'Ursprüngliche Akkumulation', Das Kapital (MEW 23), p 742, in English slightly misleading; also called 'primitive' or 'primeval'.

15 Property and/or the means of production in the broad sense.

16 Cf David Harvey (2005), The New Imperialism, Oxford UP, Oxford, pp 145-149; James K. Glassman (2006), 'Primitive accumulation, accumulation by dispossession, accumulation by "extra-economic" means', Progress in Human Geography, Vol 30, No 5, pp 608-625.

17 For an economic overview, see Margaret Slocomb (2010), An Economic History of Cambodia in the Twentieth Century, NUS Press, Singapore.

18 Cambodian Civil War (1970-75) and the Cambodian-Vietnamese War 1977/78-1989, the main front of the Third Indochina War, while the brief but intensively fought Sino-Vietnamese War of 1979, a punitive action of the People's Republic of China for Vietnamese attack on its ally Pol Pot, was restricted to the countries' borderlands; see King C. Chen (1987), China's War with Vietnam 1979: Issues, Decisions, and Implications, Hoover Institution Press, Stanford, CA. In academia there is no final consensus on when this Third Indochina War ended: 1989, 1991 (UNTAC mission) or 1999, the year of the final collapse of the Khmer Rouge military when the last leading member of Pol Pot's inner circle, Ta Mok (nom de guerre of Chhit Choeun, also known as 'Brother Number Five'), was captured by the Cambodian army; for the late Khmer Rouge, see Kevin Rowley (2006), 'Second life, second death: the Khmer Rouge after 1978', in Susan E. Cook, ed, Genocide in Cambodia and Rwanda - New Perspectives, Transaction Publishers, New Brunswick and London, pp 191-213. 
This process gained strength when Vietnamese and FUNSK ${ }^{19}$ troops entered the city. Confronted only with sporadic firefights and no prolonged resistance, Phnom Penh was declared liberated on 7 January 1979. At strategic points along the inner city perimeters, ${ }^{20}$ checkpoints were installed, guarding the most important entrances to the city. The city was divided into two parts, making the central north-south boulevard ${ }^{21}$ its border: to the east of this administrative demarcation, the Central Committee of the Kampuchean People's Revolutionary Party (KPRP) was in charge; to the west, the People's Committee of Phnom Penh (see Figure 1) was in charge. ${ }^{22}$ It is not clear for how long this division was effective or whether this separation had any practical use at all. However, it is also a fact that the supreme administrative authorities of the People's Republic established their headquarters in the former government district close to the riverside. ${ }^{23}$ Some reasons for that are obvious: the buildings were originally constructed for that purpose and the site was also the former prestigious 'heart' of the city, including the adjacent National Museum, Palace and 'Silver Pagoda' (Wat Preah Keo). Further motives for the choice, though, may be linked to the ruling state of exception and martial law. First, the district gave ample room for building up 'gated communities', which could also support each other in case of a siege or possible counteroffensive of the Khmer Rouge. Second, short distances facilitated communications and minimized the risk of exposure of the leaders during their meetings. And third, the 'rest' of the slowly re-settling city formed a security buffer against the outside, while the inner kernel of political power became a high-security zone - still effective today.

Outside the capital, party membership remained low due to these 'restrictive core group qualifications' ${ }^{24}$ The review process of political loyalty and individual trustworthiness, organized by the Central Organization Committee under Vietnamese supervision, required Cambodians to prove a 'clear personal history' (bravat roup). The sluggishness of this process forced PRK ministers to circumvent this mode of recruiting and to search for cadres and staff on their own.

All in all, Phnom Penh in the early days of the PRK bore a stunning resemblance to the topography of early modern military camps, which were vast, movable and self-sustaining 'cities' coming to a standstill. There were also many commonalities

19 Kampuchean United Front for National Salvation (Front d'Union nationale pour le salut du Kampисhéa), the political nucleus of the new Cambodian regime.

20 Today, this half-ring road is named after the Royal Cambodian Armed Forces (RCAF).

21 Boulevard Achar Mean (former Bd Monivong, re-baptized with this name after the UNTAC period).

22 Dividing Phnom Penh into different spheres stemmed from a long practice: the independent kings of Cambodia before the colonial age erected entire new palace quarters to distance themselves from the rest of the capital's residents; the French colonial period featured a predominantly 'whiteupper' and administrative city in the north of Phnom Penh; Norodom Sihanouk promoted the development of Phnom Penh's South with his new modern-style Chamkar Mon Palace as the central point of a whole new district to be built. Also, the Khmer Rouge implemented similar spatial arrangements: all Phnom Penh-based members of the Communist Party's Standing Committee were living or working either in the vicinity of the palace or in other former government locations in the centre of Phnom Penh.

23 Except for the military HQ (today's Ministry of Defence) close to the encampment/barracks/ housing of the Phnom Penh 'garrison' in the east, and the Ministry of Information which was established next to the transmitting station (on the site of the former Phnom Penh cathedral, one of the few buildings deliberately destroyed by the Khmer Rouge).

24 Gottesman, supra note 8 , at p 49. 
shared with contemporary camps of warlords ${ }^{25}$ In these spatial arrangements, the most important part - the quarters of the commander (and 'war entrepreneur'), his senior officers, families and friends in the middle, watched over by handpicked personal bodyguards - was concentrically enclosed by other troopers (and their families) according to rank and branch of the force. ${ }^{26}$

As in the high times of mercenary armies in Europe, the leadership of the young People's Republic did not trust the people with which it surrounded itself. However, the elites had to accept their proximity for the sake of a common objective security and the building of stable neighbourhoods to reboot normal life. For the elites of the new regime, the immediate neighbourhood became the site for the 'original accumulation' of political power by reciprocity. This was achieved in two ways. First, only a reliable entourage of the Khmer government in Vietnamese exile was entitled to have the first pick of its housing within the 'government district' (the gated high-security area, which still persists today, see Figures 2 and 3). This constituted the 'inner circle'. At the same time, outside the government quarters, trustworthy members of committees allocated living space to the first repatriates and refugees in the other districts of Phnom Penh. The 'rest of the city' was, thus, systematically assigned to ordinary 'comrades'.

\section{The formation of the PRK government district as a 'civic centre'( 'cité')}

The affair of 'comrade Kann Man' is instructive for the first case - the workings of the 'inner circle' or 'core group' of power. In his capacity as designated foreign minister of the shadow government, Hun Sen issued a limited carte blanche to Kann Man, a member of his hand-picked staff, granting him the right to take into possession any house of his choice (within the foreseen compounds of the foreign ministry). The form left blank some space to write in the address, but Kann Man did not fill it in. Nevertheless, he rightfully occupied House No 387, Rue Karl Marx (Quai Sisowath during the PRK). The form (a hectograph), dated 24 December 1979, already featured the national emblem and a stamped seal of the PRK, although the latter was not officially declared a state until 12 January 1980. One year after the invasion of Pol Pot's 'Democratic Kampuchea' began, Hun Sen signed a real estate voucher, but only for a limited amount of time. This 'temporary certification', as it was translated, was to be submitted for approval to the Revolutionary People's Council and to the Municipal Committee of Phnom Penh City. The governor of the city ('Brother Khang Sarin'), ${ }^{27}$ had countersigned the certificate on the same day, 24 December, at $6.35 \mathrm{pm}$ local time. The minister, however, reserved the exclusive right to make the final decision, which also sealed a personal bond. Later, this 1979 document found its way into a complaint file that the beneficiary submitted to UNTAC. Kann Man was looking for help after

25 For Early Modern Europe, see Geoffrey Parker (1996), The Military Revolution: Military Innovation and the Rise of the West, 1500-1800, Cambridge UP, Cambridge; and for modern 'war lords', Mary Kaldor (1999), New and Old Wars. Organized Violence in a Global Era, Stanford UP, Stanford, CA; or Sarah K. Lischer (2005), Dangerous Sanctuaries: Refugee Camps, Civil War, and the Dilemmas of Humanitarian Aid, Cornell University Press, Ithaca, New York.

26 To understand the different types of power practices of the anti-PRK groups, see Daniel Bultmann (2015), Inside Cambodian Insurgency: A Sociological Perspective on Civil Wars and Conflict, Ashgate, Farnham.

27 One of the Khmer exiles with the rank of Major in the Vietnamese Army and first Governor of Phnom Penh (1979-80); for him and further exiles, see Chanda, supra note 5, Chapter 7. 
he had fallen out of Hun Sen's favour and into disgrace. He was arrested during UNTAC, and his career ended in one of the infamous PRK-SOC prisons. ${ }^{28}$

The case illustrates that each minister became the pivotal point for an inner circle of political authority. The various ministerial compounds turned into trading grounds for loyalty, which made them into gravity fields for networks of secondary and tertiary 'circles'. At an organizational level, these prime political urban neighbourhoods were to be self-sufficient: that is, the management of social life and the meeting of their material needs were modelled on rural krom samaki ('solidarity groups' or 'cooperatives'), which formed a unit of living and working for industrial production in state-owned companies, or the cultivation of collectivized land ${ }^{29}$ This socialist way of living was never popular amongst Cambodians, and never took root. The urban compounds, which Adeline Carrier fittingly names 'cités' ${ }^{30}$ were privileged insofar as they offered the most security and access to goods (even though the PRK government tried to avoid unequal treatment in terms of provision) and - most importantly - proximity to power and decision makers. Hun Sen (and others) became a patron not only thanks to the pressure of Vietnamese bayonets, but also because he could provide for the daily needs of his protégés. Housing was the key resource in that respect, and accommodation in these 'cités' implied a privilege to be earned. To enhance his own symbolic capital, Hun Sen picked the location of his private residence after careful consideration: it faced the Independence Monument ${ }^{31}$ commemorating liberation from France..$^{32}$

It should be noted that any patron of a district had to respect a delicate political balance of loyalties: 'corruption' was systemic and worked in this rudimentary state apparatus both top-down and bottom-up. It constituted a reciprocal process. Such pyramidal networks of clienteles encompassed a mixture of 'direct' and 'indirect' rule. For the upper and top echelons, 'direct rule' meant entourage: to force others into 'the shadow of his name', as Marcel Mauss puts it. ${ }^{33}$ For example, Hun Sen and Chea Sim, partners as well as opponents in the internal power struggle for the new rule of these years, could exercise face-to-face control only of their inner circles. In doing so, they had to turn a blind eye to arrangements made by members of lower ranks, in which their (deepest) shadows started to fade.

'The regime had thus created a state apparatus, bestowing upon its cadres power

28 NAC/UNTAC.Box 18/1. Phnom Penh.CYA/AN/AC/ER/PP/105 - KANN MAN (all translation into English provided and attached by UNTAC translators).

29 Slocomb, supra note 17, at pp 175-229.

30 'Cité', in French, bears the extended meaning of 'cité administrative, ouvrière', etc, to designate a civic centre, production site, etc. Additionally, it refers here to the situation of a gated community ('city in the city').

31 It was erected in 1958 and stands at the intersection of Norodom and Sihanouk Boulevards; another highly symbolic location is situated further east: the Cambodian-Vietnam Friendship Monument erected in 1979 to commemorate the eternal socialist brotherhood of the two peoples and as a reminder of the Vietnamese soldiers killed in action for the liberation of Cambodia (see Figures 2 and 3).

32 In his authorized biography, he explained: 'At that time, there was no residence for a foreign minister, but here were so many empty houses in Phnom Penh - everybody could choose one,' he said. 'I could get 300 houses if I wanted.' Harish C. Mehta and Julie B. Mehta (1999), Hun SenStrongman of Cambodia, Graham Brash, Singapore, p 90.

33 Marcel Mauss $(1954,2006)$, The Gift - Forms and Functions of Exchange in Archaic Societies (with an introduction by E.E. Evans-Pritchard), Cohen \& West, London, pp 38-39. (The three obligations: giving, taking, repaying); Techniques, Technology and Civilization (edited by Nathan Schlanger), New York. 
and access to goods without making them accountable. The system was "anarchic" (anathibatey), according to government reports. ${ }^{34}$

This necessary laissez-faire policy of flexible limits also left an imprint on the urban morphology of Phnom Penh, which is still visible today. Let us use the foreign ministry compound again as an example, but this time looking at it 'bottom-up' from the political foot soldier's viewpoint.

Originally, the personal bodyguards of Hun Sen and Chea Sim, being members of their 'households', ${ }^{35}$ were assigned to a block south of the state guest house ('Hôtel d'état'), which hosted gradually more and more family members, soon also friends, later even friends-of-friends (see Figures 2 and 3) ${ }^{36}$ Eventually, the property was rented out or 'sold', not respecting the ban on dividing this plot of land into lots (which explains the microstructure of the houses compared to the neighbouring buildings). In fact, the original 'owners' were only usufructuary of (e)state assets and, by law, not entitled to deal with their value in kind. The need to let the followership take its share prevented the prosecution of any abuse as long as the political standing of the patrons was not yet cemented - except in the case of treason, when the above-mentioned comrade Kann Man was accused of the worst-case scenario of malfeasance. ${ }^{37}$

Assigning self-sufficiency to these 'sub-units' left them with ample leeway, and was also in harmony with the traditional custom that 'land belonged to the tiller': that is, the peaceful occupation of land in accordance with the neighbours and, as a second precondition, its continued use (continuous possession). Any violation of these usages would have been regarded as despotism and disregard for order, which the new leaders had promised to restore after the nightmarish revolutionary rule of the Khmer Rouge. From the beginning, the political top ranks could not act as absolute, but only as restrained 'kings'. In their 'cités', they were virtually 'encircled', and their power was held in check by their clients' interests and expectations. The creation of a sustainable power structure depended on preferential treatments and cooperation of the individual patron's followers, who expected to receive their appropriate shares. These arrangements and hierarchies, however, also had to be in accordance with the other cliques and factions that shared the same (physical) camp.

\section{The 'rest of the city': the resettlement of the surrounding quarters}

Left unattended for years in a tropical monsoon climate, the buildings of Phnom Penh suffered considerably more from environmental impacts than from Khmer Rouge vandalism. About a quarter of the buildings, especially the wooden houses, were structurally unsound or damaged. An inventory and assessment listed 56,560 destroyed or uninhabitable units in total. However, the same investigation, conducted

Gottesman, supra note 8, at pp 96, 320.

Also called Chea Sim's konchau (literally 'children and grandchildren' in Khmer).

36 This section is based on five investigative interviews (snowball sampling) with interpreters, January 2012.

37 In 2011, Chea Sim (1932-2015), former President of the Senate and of the Cambodian People's Party, seized his long-term bodyguard, Chief Lieutenant General Chhoeun Chantan, who started his career in this neighbourhood (when Chea Sim was President of the National Assembly and the grey eminence of the CPP), after Prime Minister Hun Sen named him as one of several military officials involved in corrupt activities; see The Phnom Penh Post, 15 August 2011 - meanwhile, he was sentenced to 26 years in prison. 
by the People's Committee of Phnom Penh, ${ }^{38}$ also noted the fact that a sufficient amount of houses remained basically intact. The redistribution of this housing resource followed a specific topographical and social pattern. ${ }^{39}$ Phnom Penh's best-preserved urban structure was to be found around the market halls. The edifices in these urban areas of high building density were executed in the style of concrete 'shop houses' with at least two to three floors above the sales, service or workshop area of the entrance foyer. For commercial purposes, such quarters were also the most sought-after, and the ones close to the city centre were the first blocks to be assigned. To prevent a disorderly and chaotic repopulation of the capital, the Party Central Committee established an inter-ministerial body: the 'Committee for the Establishment of Social Order and Security for the Capital of Phnom Penh'. The social principle behind the assignment policy was twofold: the demands were treated (a) in chronological order - first in, first served - according to a (b) ranking of social needs, with priority given to widows with children, families, single women, older followed by younger couples, and finally, bachelors. My interview partners unanimously agreed that the local PRK People's Committees respected this principle in order to build up trust and reciprocity. However, they also remarked that flexible interpretations and creative manipulations of the standards soon occurred on both sides..$^{40}$ Usually, refugees or returnees who applied for access to the city were initially 'filtered' at the military checkpoints along the urban periphery. There, spontaneous alliances (or bribes) on the spot could be helpful, as when, for example, a Khmer family was rewarded for its care of a war orphan waiting in the queue at a checkpoint. The latter could speak Vietnamese and persuaded the guards to let her new family in. ${ }^{41}$ Like all the others before and after, these prospective new inhabitants were also brought to a demarcated transit zone (usually empty market halls or other premises), where their social and political status and needs were assessed before the allocation of housing was decided. Allocation was granted either after an official hearing or informally by the officials in charge. Bribes and small favours could accelerate the process and could also influence the choice of real estate, which was basically not foreseen in the proceeding.

A review of Phnom Penh's resettlement outside the 'cités' during the first couple of years topographically reveals decentred concentric circles of occupational

38 Ben Hong Kry (1987), La résurrection de la ville de Phnom Penh après la libération du 7 janvier 1979, Comité Populaire de Phnom Penh (mai 1987), Phnom Penh; see also footnotes 42 and 43.

39 This section is also based on 100 semi-structured interviews with interpreters, January 2012 , randomly investigating shop owners and their location decision for this particular site. The framework of themes to be explored included the questions of property and original assignment by the authorities or later purchase of urban space; see Thomas Kolnberger (2012), 'Phnom Penh nach der urbanen Katastrophe - "Alltägliches Geographie-Machen" am Beispiel der Standortentscheidungen von Wirtschaft und Handel in einer südostasiatischen Metropole', Mitteilungen der Österreichischen Geographischen Gesellschaft, Vol 154, pp 235-260.

40 'The Party's effort to stop state officials from hiring friends and family had failed, offering thousands of Cambodians the opportunity to live in the City. [...] In the summer of 1980, the regime attempted to reverse the flood by ordering municipal officials to send people back to the countryside and by compiling a list of families authorized to stay. It was too late; by the end of the year, Phnom Penh was home to more than three hundred thousand people.' Gottesman, supra note 8, at p 76.

41 Interview with owner of house No 15, Street 135/Corner Street 446, Chamkar Mon, close to the so-called Russian Market, conducted 22 December 2011 (the only family in the entire neighbourhood to have stayed in the same place since 1980). 
density around the former market areas (settlement concentration in pockets). In general, the population density was highest in the old city centre (for example, the Central Market area) and declined progressively towards the periphery due to security reasons and the quality of building structures. This relatively extensive primary occupation underwent a process of intensification. Until the mid-1980s, the city had virtually 'filled up' laterally and vertically, as more and more people shared the space with latecomers (see Appendix). It became an advantage for someone from the outside to know someone already established in the city, a person who could provide accommodation and grant a kind of advanced clearance certificate to the People's Committee and the party warden of the block or subdistrict. The pyramidal laissezfaire principle of the 'cités' was repeating itself on the micro level, as access to city housing was valuable (and could be sold or 'reserved' for relatives or family). Similarly, 'chains of sales' can be observed - that is, the proliferation of illegal and informal selling of what was technically state property and the original accumulation of petty capital in the lower ranks of the party.

The main difference, besides the difference in value, between the outer urban areas and the 'civic centre' of the political elite and their entourage was that the former had no particular security-zoning or social features like the gated communities of the 'cités'. There were no immediate 'shadows' of the paramount political leader. People who had successfully passed the gatekeepers were only expected to be calm, orderly and loyal to the regime.

To recapitulate: the process of repopulating Phnom Penh by allocating 'first choice' of housing was intentionally biased from the beginning. The urban space served as a means for social differentiation, since 'first served' order was not strictly observed, nor a chronological 'first come'- but rather operated in a political economy of space, separating the common people from the political elites in senior, junior and subordinated ranks of party leaders and apparatchiks. Asset value was assigned according to the status of applicants, as a result of which habitable real estate - about one-quarter of the available housing before the Khmer Rouge ${ }^{42}$ - was categorized as follows: 9,017 'villas' (representative detached or semi-detached houses spaced apart from the streets, usually with a garden); 4,972 'maisons' (regular single houses, usually one- or multiple-family dwellings); and 31,752 'compartiments' (apartments). 'Villas' and 'maisons' were again subdivided according to size and furnishing into nine categories ('classes'). The hierarchy of entitlement to official lodgings was then specified by a decree of the PRK in 1982, which itself was modelled on the Vietnamese practice of five categories of civil servants/functionaries (classes A-E), ranging from ministers down to simple party officials and operatives. ${ }^{43}$

42 On the refugee situation and its impact on Phnom Penh's urbanism before 17 April 1975, see Someth Uk (1975), 'Phnom Penh et son évolution urbaine', Planification-Habitat-Information (PlanningHousing-Information), (Secrétariat des missions d'urbanisme et d'habitat, Paris), Vol 79, Février, $\mathrm{p}$ 42 (map 10); J.C. Allaire (1971), Utilisation des terrains urbains en République Khmère, Projet "Direction de l'urbanisme et de l'habitat", annexe numéro 4 au rapport périodique numéro 1, Paris.

43 Carrier, supra note 11, at pp 205-207, 288 ; and Laurent Pandolfi (2001), 'Une terre dans prix, réforme foncière et urbanisation au Viêt-Nam, Hanoi, 1986-2000', PhD dissertation, University of Paris VIII, p 64. Why only about a quarter of the available housing was categorized is not fully comprehensible (see footnote 38). In parts, however, the difference may be explained by the exclusion of spontaneous, habitable refugee settlements of Phnom Penh erected during the Khmer Republic. Second, the counting of apartments gives no clear indication whether the count considers single accommodation units (single flats or apartments as part of a bigger housing unit) or apartment blocks (or shop houses, which can have multiple floors). Nevertheless, these figures represent the official stock for the redistribution of housing space. 


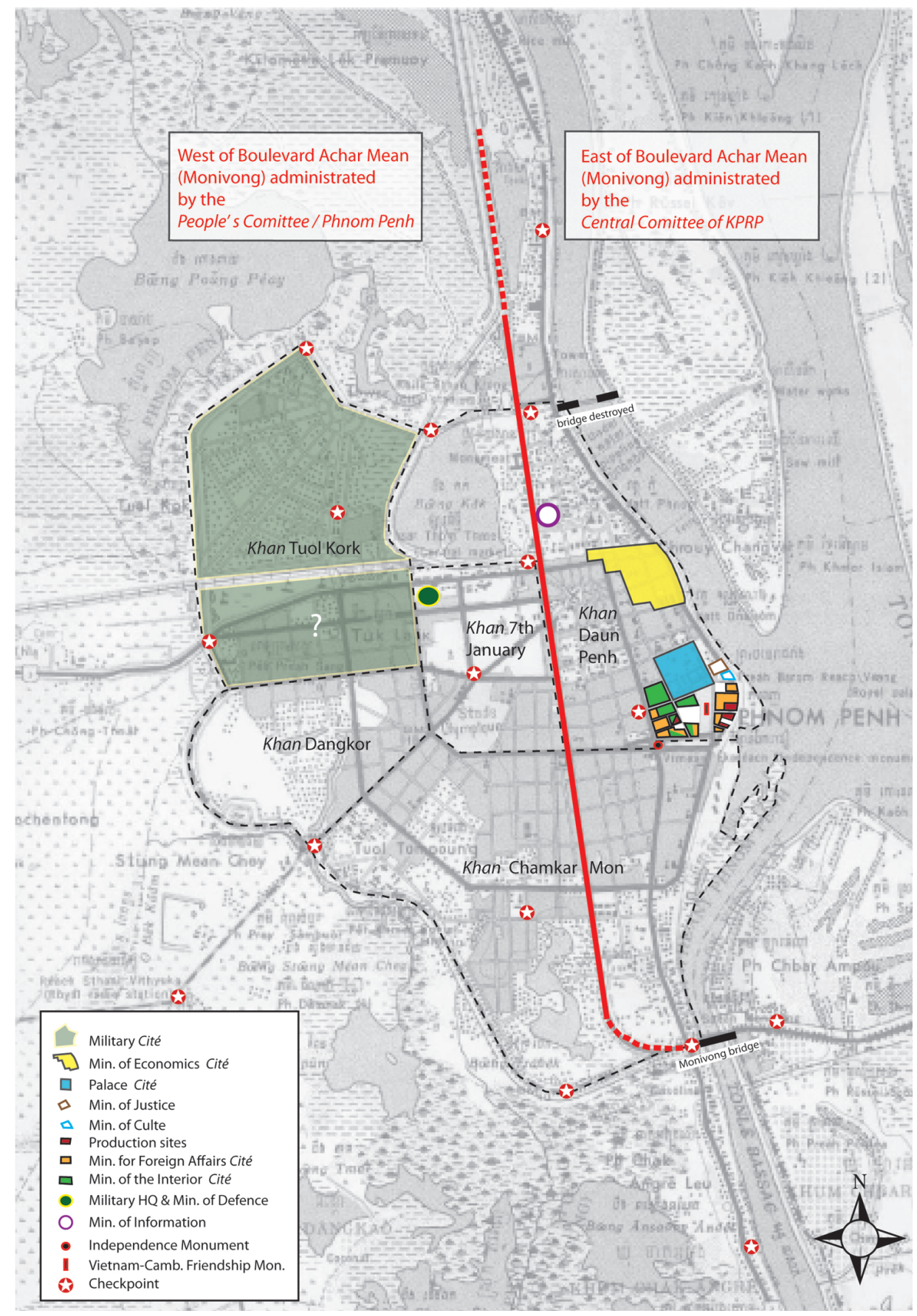

Figure 1. The first political division of the city and the location of the 'cités' in Phnom Penh, 1980.

Source: Own draft based on Adeline Carrier (2007), 'Les "lois de la possession" à Phnom Penh: conversion des droits d'usage résidentiel issus du contexte socialiste de réappropriation urbaine (1979-1989) en droits de propriété', PhD dissertation, Paris VIII; and US Army Map Service, Phnom Penh 1963 (detail). 

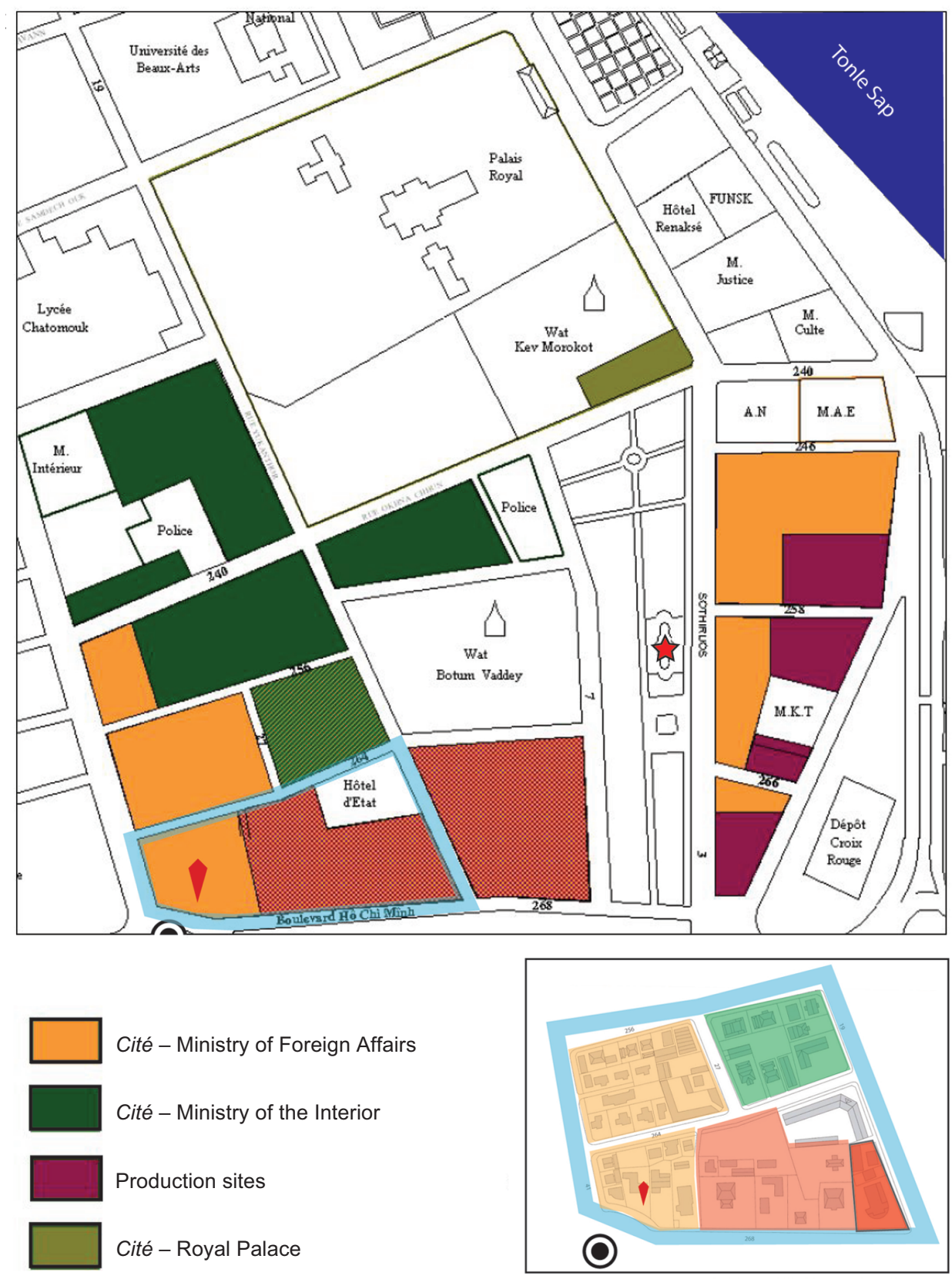

Cité - Ministry of Foreign Affairs

Cité - Ministry of the Interior

Production sites

Cité - Royal Palace

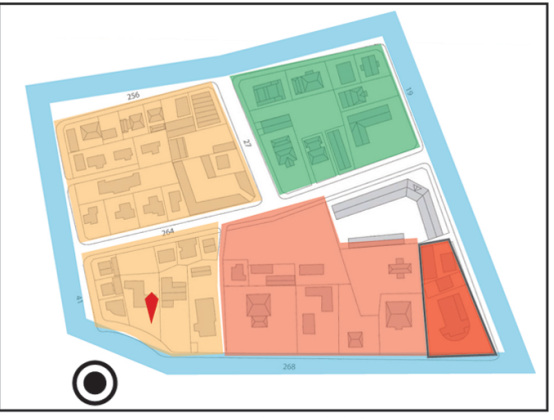

Krom mixed: Cité - Ministry of Foreign Affairs and production site

Detail: Area NW of Independence Monument

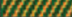

Krom mixed: Cité - Ministry of Foreign Affairs and of the Interior

Figure 2. Close-up of different 'cités' in Phnom Penh, 1980, with details of the situation in the compounds of the Ministry for Foreign Affairs, the residence of Hun Sen and the block of the (former) bodyguard settlements.

Source: Own draft based on Adeline Carrier (2007), 'Les "lois de la possession" à Phnom Penh: conversion des droits d'usage résidentiel issus du contexte socialiste de réappropriation urbaine (1979-1989) en droits de propriété, PhD dissertation, Paris VIII, p 223. 

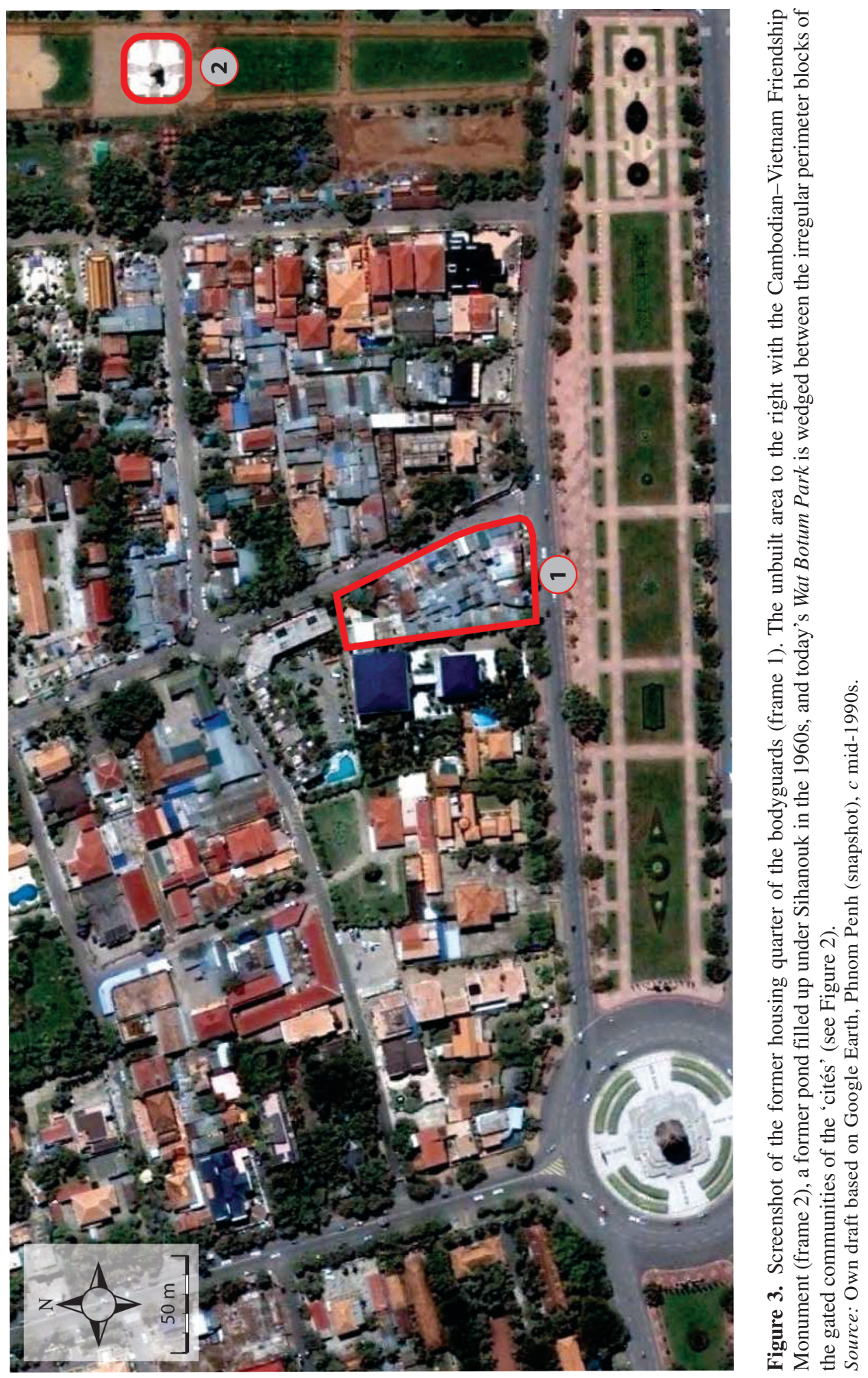
From a juridical point of view, Phnom Penh's real estate was declared ownerless by the new regime. This tabula rasa was to avoid future conflicts with returnees claiming their former property. A convenient side effect was that the year zero of Cambodia's ownership status also legalized the official confiscation of property in favour of the emerging PRK apparatus; its elite could pick prime estates. Finally, the expropriated fixed assets became the social capital of an emerging socialist society. This urban situation formed a notable contrast to the countryside. In rural areas where land was plentiful, local authorities did not intervene in the efforts of returnees to reclaim their former properties. Cases of conflicting interests could be settled amicably by occupying another place. ${ }^{44}$

The logic of scarcity of accommodation, which led to the establishment of a new hierarchy, thus represented one side of the new regime's steering process, while the need for a jointly responsible 'moral' during the shortage economy of the initial years constituted the other side of the coin. This 'moral economy'45 operated in small, closely knit neighbourhoods. It was challenged by the 'peace in sight' politics of the late 1980s, dissolving the physical camp-like situation and, concurrently, by free market principles, virtually 'c(r)ashed-in' during UNTAC in the early 1990s.

\section{UNTAC: the transition of Cambodia's bipolar demography}

After losing control over most Cambodian territory to the Vietnamese (and the Cambodian Government of PRK in Phnom Penh), the Khmer Rouge survived politically along the Thai-Cambodian border, embedded in an 'archipelago of refugee camps' ${ }^{\prime 6}$ which formed their military and economic power base. At the height of its mission, the United Nations Border Relief Operation (UNBRO) supported about 300,000 people..$^{47}$ In a civil war economy ${ }^{48}$ surreptitiously linking local shadow economies with the global market, people also became a resource in terms of (military) manpower and material support. Two non-communist guerrilla factions ${ }^{49}$ joined this rump state in 1982, forming the so-called Coalition Government of Democratic Kampuchea (CGDK). This government in exile, a pure construct according to international law, with Prince Norodom Sihanouk as

44 May Ebihara (1990), 'Revolution and reformation in Kampuchean village culture', in David A. Ablin and Marlow Hood, eds, The Cambodian Agony, M.E. Sharpe, New York and London, pp 33-34.

45 James C. Scott (1976), The Moral Economy of the Peasant: Rebellion and Subsistence in Southeast Asia, M.E. Sharpe, Princeton, NJ.

46 Christel Thibault (2008), L'archipel des camps - L'exemple cambodgien, Paris; Christel Thibault (2005), 'Conflits, refuges et enjeux frontaliers - Les déplacements forcés de la population du Cambodge 1970-2000', PhD dissertation, Université de Paris IV.

47 Between 1979 and 1990, the support amounted to US\$940 million: the Thai-Cambodian relief operation was labelled as the 'Rolls-Royce' of international aid by an NGO member cited in Charlotte Benson (1993), 'The changing role of NGOs in the provision of relief and rehabilitation assistance: case study 2 - Cambodia/Thailand', draft ODI working paper, Overseas Development Institute, Regent's College, London, pp 5-6, 20.

48 Christian Lechervy (1996), 'L'économie des guerres cambodgiens: accumulation et dispersion', in François Jean and Jean-Christoph Rufin, eds, Economie des guerres civiles, Hachette, Paris, pp 189-232.

49 The royalist FUNCINPEC (Front Uni National pour un Cambodge Indépendant, Neutre, Pacifique, et Coopératif) under Norodom Siahnouk and the 'liberal-republican' KPNLF (Khmer People's National Liberation Front) under Son Sann, together with the expelled Khmer Rouge (officially now Party of Democratic Kampuchea, PDK) - formed the exile government, CGDK, later renamed the National Government of Cambodia (NGC). 
its nominal figurehead, was supported by 'the West' ${ }^{50}$ and China. During the last stage of the Cold War, the CGDK represented the countervailing power of the Phnom Penh regime and the Soviet Union as its global patron. ${ }^{51}$

As probably the last significant act of the bloc confrontation, ${ }^{52}$ the East and West agreed to unite the 'two Cambodias' by name in the follow-up to the UNsponsored Paris Agreement conferences of $1989-91 .^{53}$ The provisional 'State of Cambodia' (SOC) should serve not only as a 'neutralized' zone by name, but as an internationally monitored environment for the transition from civil war to a postconflict society. A peace mission was brought into being: the United Nations Transitional Authority in Cambodia (UNTAC). Its mission consisted of preparing the ground for fair and democratic first national elections, which included the surveillance of the integration process of displaced persons from the border camps and of the full withdrawal of Vietnamese troops..$^{54}$

UNTAC was to administer and control the SOC in cooperation with the Supreme National Council of Cambodia (SNC), which constituted the unique legitimate body and source of authority throughout the transition. The SNC served as a quadripartite interim authority representing the four civil war parties under the chairmanship of Prince Norodom Sihanouk. ${ }^{55}$ On paper, and after an advance mission (UNAMIC) ${ }^{56}$ UNTAC took full interim responsibility for overseeing foreign affairs, defence, finance, public security and information on 1 July 1992, making the SOC technically an international protectorate of domestic and external affairs for a limited time. That date was a diplomatic fiction, as the full deployment of UN administration staff was delayed and was not considered complete until 27 September. ${ }^{57}$

UNTAC consisted of seven distinct components: human rights, civil administration, electoral, military, police, repatriation and rehabilitation. The civil administrative sector was to assure a 'neutral political environment conducive to free and fair elections', according to article 6 of the Paris Peace Agreement. Soon, however, the PRK/SOC administration realized the weak performance of the UN supervision due to a hesitant, partly contradictory practice within and between almost all components. ${ }^{58}$

50 The USA, US allies in Europe and members of the Association of Southeast Asian Nations (ASEAN, founded 1967).

51 It even retained the UN seat of Cambodia until the end of the Cold War, when the seat was left vacant from October 1990 until the Paris Agreement one year later.

52 The USSR was formally dissolved on 26 December 1991; cf Bernd Stöver (2011), Der Kalte Krieg - Geschichte eines radikalen Zeitalters, 1947-1991, C.H. Beck, München.

53 At the first peace conference in Paris (Paris International Conference on Kampuchea, PICK), 30 July to 30 August 1989 , all four delegation members of the civil war parties sat side by side behind the long label plate 'Cambodge'; a comprehensive settlement was signed two years later on 23 October 1991 at the second Paris conference (Paris Conference on Cambodia, PCC).

54 Various estimations of the number of Vietnamese troops in Cambodia until the 1980s range from 100,000 to as many as 200,000; see the summary by Michael Vickery (2007), Cambodia: A Political Survey, Funan Press, Phnom Penh, pp 20-32.

55 A balance of six seats for the SOC and six for the opposing civil war parties (two each for FUNCINPEC, KPNLF and DC/Khmer Rouge).

56 United Nations Advance Mission in Cambodia (October 1991-March 1992).

57 400-500 staff were earmarked for the civil administration; see Jarat Chopra (1994), United Nations Authority in Cambodia, Occasional Paper No 15, Thomas J. Watson Jr Institute for International Studies, Brown University, Providence, RI, p 32.

58 The efficiency and performance of the UN mission in Cambodia is still highly disputed. For a critical, but fair and comprehensive analysis with special regard to the military component, see Peter Hazdra (1997), Die UNO-Friedensoperation in Kambodscha - Vorgeschichte, Konzept, Verlauf und kritische Evaluierung des internationalen Engagements, Europäische Hochschulschriften, Reihe XXXI, Vol 322, Peter Lang, Frankfurt/Main. 
Moreover, the reputation, good standing and initial prestige of UNTAC among the population deteriorated quickly for diverse reasons. ${ }^{59}$ Nevertheless, a 'Complaints and Investigation Service' within the civil administration began to deal with growing numbers of petitions of Cambodians against the SOC administration. ${ }^{60}$ As it turned out, the SOC authority and its political arm, the Cambodian People's Party (CPP),${ }^{61}$ had obviously never lost their grip on Cambodia's governance. From the beginning the SOC, dominated by the CPP, played for time and tried to safeguard political power. The party members' control of real property and economic resources helped to buttress this claim to leadership.

Indeed, UNTAC officials were taken by surprise: they had expected more cases of 'classical' political harassment. ${ }^{62}$ Instead, an unanticipated high caseload of disputes about ownership and property led to the formation of a specific 'Complaints Clarification Committee (CCC)', which operated across the country. Politics and property were inextricably connected in such a way that these 'apolitical' disputes - in its view - had the potential to threaten social peace and the ultimate goal and raison d'être of UNTAC: fair elections. Even in the face of months-long intimidation by increasingly aggressive Khmer Rouge attacks on UN personnel, which peaked in March 1993, the elections were never in (geo)political danger: no 'interested third party' for supporting a proxy war interfered any longer. ${ }^{63}$ What the UNTAC authority witnessed and documented, however, was a struggle for the distribution of privileges and scarce resources in the final phase: the definite privatization and capitalization of usufruct and common good for the time after the UN mission had left. ${ }^{64}$

\section{The files of UNTAC's CCC and their context}

It appears that the CCC, as a special branch, officially started its work on 17 September 1992, after more than 163 complaints had already been collected by UNTAC. First we investigate the questions of numbers and timing and offer a preliminary

59 UNTAC/APRONUC, Interoffice Memorandum (Executive Summary) by Judy Ledgerwood to Timothy Carney/Information-Education Program of 18 September 1992, Phnom Penh.

60 Michael W. Doyle (1995), UN Peacekeeping in Cambodia: UNTAC's Civil Mandate, Occasional Paper Series, International Peace Academy, Boulder, CO.

61 Party formerly known as KPRP (Kampuchean People's Revolutionary Party), renamed in 1991 after officially dropping its commitment to socialist ideology.

62 For instance, the search of premises of one of the 20 parties running for the election clearly constituted a violation of the UN agreement. But, to keep handguns, semi-automatic weapons, even a grenade launcher in a secret weapons stash, was illegal too: in Phnom Penh at this time, a simple distinction between right and wrong did not exist; see NAC/UNTAC.Box 1/1.Daun Penh: 4.025 - SOK SARATH, Rassemblement pour la Solidarité Nationale.

63 In the meaning of 'Interessierter Dritter', according to the concept of Carl Schmitt (1995), Theorie des Partisanen - Zwischenbemerkung zum Begriff des Politischen (4th German edition of 1963 Theory of the Partisan), Duncker \& Humblot, Berlin, pp $79 \mathrm{ff}$; and Rolf Schoers (1961), Der Partisan - Ein Beitrag zur politischen Anthropologie, Kiepenheuer \& Witsch, Köln, pp 247 ff. Beijing withdrew any support for the Khmer Rouge in 1993; Sorpong Peou (2000), Intervention \& Change in Cambodia - Towards Democracy? Institute of Southeast Asian Studies, Singapore, pp $381 \mathrm{ff}, 405$.

64 "The one area in which "privatization" has made considerable headway is commercial and residential property. In Phnom Penh alone, since 1989 some 100,000 units have been made private. Too often, the neo "owners" have been well-placed party officials who, in effect, have transferred state assets to themselves, often leasing them to foreigners at a handsome profit.' Contemporary analysis by George Irvin (1993), Rebuilding Cambodia's Economy: UNTAC and Beyond, April, Working Paper Series No 149, Institute of Social Studies, The Hague, p 14. 
interpretation: a quantitative summary for Cambodia shows that the CCC registered a total of 1,252 complaints, 300 of which were in Phnom Penh alone. This means that, on average, one new complaint was filed every second day for the entire period of the UN mandate. The caseload represents the small evident part of the phenomenon. First of all, only 12 out of 21 provinces were investigated and, in general, only one specific category of Cambodians seemed to file complaints with the UN - the one disappointed by the SOC authority's role.

Judging from Judy Ledgerwood's sobering report on the perception of UNTAC at the mid-term of the mission, UNTAC continued to be a point of contact for appeals:

'With regard to matters of protection of the rights of individuals - in cases of corruption, land disputes, and protection from perceived ill treatment by SOC administrative structures - UNTAC is widely viewed as either hopelessly inept or in collusion with SOC authorities' ${ }^{65}$

In Phnom Penh, 163 cases were filed before and, despite the critics, 147 after the report in September 1992. In the absence of alternatives, the UNO was considered to be a potential patron for those whose social connections - ksae, which literally means 'strings' in Khmer-had become too 'short' and weak to protect their interests. ${ }^{66}$

Even loyal state functionaries, the backbone of the communist regime, were affected, as the statement of a middle-ranking official in Kampot translated into English by UNTAC interpreters shows:

'We are one of the foreman which serving the state for 14 years ... in the meantime we always respect to the discipline, the assignment of the party and the state properly go down to the field for long time or short time. [...] During 14 years, the actual result which I had received are only admirable letter and admirable certificate. [...] I want you to find the justice for me because some can have public lands or warehouse as their possession, why not me?' $[s i c]^{67}$

'Why not me?' was the tenor of many complaints, as others were seen to 'grab' public properties or were allowed to privatize their provisional right of use permanently, including official land registration. In anticipation of a stable peace, the established pecking order dissolved, and better connected people took their chance to enrich themselves.

'Why me?' was the complementary question. Others, for example, were not compelled to share their spacious estates in times of scarce residential space, as a former vice-president of the Cambodian Red Cross complained. After being retired, she was forced to share the housing space of her 'villa' ${ }^{68}$

65 UNTAC was specifically blamed for problems of public security, sexual harassment of male personnel, reckless driving, etc; see UNTAC/APRONUC, Interoffice Memorandum (Executive Summary) by Judy Ledgerwood to Timothy Carney/Information-Education Program of 18 September 1992, Phnom Penh (no page numbers).

66 Historically, in Cambodia a highly differentiating terminology for economic and political 'leaders', authorities and representatives has developed; see Cambodia Development Resource Institute (CDRI) (2009), A Study of Leaders in Three Communes of Three Provinces (v. Thon Vimealea, Ou Sivhuoch et al), CDRI Working Paper Series No 42, Phnom Penh, especially p 31.

67 NAC/UNTAC.BOX 16/2. Kampot - B53 - SOK DARA, Chief of Planning vs. Provincial Authorities.

68 NAC/UNTAC.BOX 5/2. Tuol Kork: 36.265 - PUM CHANTINE. 
Table 1. Overview of pending and closed complaints to CCC, Cambodia, 1992-93 (complaints caseload: provinces, partial results) ${ }^{\mathrm{a}}$

\begin{tabular}{lcccc}
\hline Complaint & House/land & Harassment & Other & $\boldsymbol{\Sigma}$ \\
Active cases & 331 & 42 & 46 & $519^{\mathrm{b}}$ \\
Closed cases & 208 & 218 & 207 & 633 \\
Total & 539 & 260 & 253 & $\mathbf{1 , 1 5 2}$ \\
\hline
\end{tabular}

Note: ${ }^{\mathrm{a}} 12$ out of 21 provinces including Phnom Penh. ${ }^{\mathrm{b}}$ Including an estimation of 100 cases for Prey Veng (province).

Source: NAC/UNTAC.BOX 18/1. POLICIES/GUIDELINES - UNTAC Complaints \& Investigations Service (CIS), Statistical Report 1992 (annex 1, 1a) Intern Office Memorandum C.A.7 (STATREP), 15 February 1993.

Table 2a. Complaints caseload: Phnom Penh, 1992-93.

\begin{tabular}{lcccc}
\hline Complaint & House/land & Harassment $^{\mathbf{a}}$ & Other & $\boldsymbol{\Sigma}$ \\
Active cases & 166 & 1 & 25 & $192^{\text {b }}$ \\
Closed cases & 96 & 2 & 10 & 108 \\
Total & 262 & 3 & 35 & $\mathbf{3 0 0}$ \\
\hline
\end{tabular}

Note: 'Including 49 cases classified as 'stalemate', whereas 143 pending cases were considered as negotiable/solvable (see Tables $2 \mathrm{~b}$ and $2 \mathrm{c}$ ). ${ }^{\mathrm{b}}$ 'Note: Harassment cases only include those complaints brought to us by private individuals and NOT those referred by political parties.'

\begin{tabular}{lr}
\hline Table 2b. Cases classified as 'stalemate'. \\
\hline x C & 24 \\
X M & 13 \\
x I & 10 \\
x D & 2 \\
x (1975) & 6 \\
Total & $\mathbf{4 9}^{\mathrm{a}}$ \\
\hline
\end{tabular}

Note: ${ }^{a}$ Excluding the six cases classified as ' $\mathrm{x}$ (1975)'; see Table 2c.

Table 2c. Definitions of stalemate cases.

x C Cases generally involving the Council of Ministers and other higher institutions where it is judged there has been an abuse of authority and UNTAC does not agree with the decision but has been powerless to bring about any reversal or correction of the situation. Alternatively, cases where there are disagreements between the judicial and administrative institutions which result in nothing that can be implemented.

x M Cases involving the Ministry of Defence or individual military where we have been Cases involving the Min
unable to take action.

x I Cases where we agree with the decisions but local authorities either refuse or are unable to implement due to interference.

x D Cases so complex or lacking in formal detail that they are unlikely ever to be solved. $\mathrm{x}$ (1975) Closed as claim for ownership pre-1975.

Sources (Tables 2a-2c): Final statistics of CCC for Phnom Penh, 1992-93. NAC/UNTAC.BOX 18/1. COMPLAINTS CASES - GENERAL. NAC/UNTAC.BOX 18/1. POLICIES/GUIDELINES - UNTAC.

A new nexus of money and political connection reigned, taking advantage of those in a weak position in the hierarchy. In particular, 'unconnected' commoners, notwithstanding their well established rights to their living space, could be ripped off for dubious reasons: 
'Mr MEA SUP [wants] my land who insulted me with obscene words and menaced me with his pistol. If I don't obey, my house will be urgently leveled in a period of 5 days.' $[\text { sic }]^{69}$

Mr Y. Neang had rightfully occupied a very well situated house since 1980. All of a sudden, he was forced to sell the property for US\$400 - a fraction of its actual value. An alleged infringement of the building law served as a pretext.

Individuals, as well as groups with conflicting claims to land and housing, applied to the UN. One not unusual case even involved a three-way dispute over the ownership of land close to Kampot/Sihanoukville: 50 workers of a former local industrial site of the PRK laid claim to 50 plots of land. They had resettled there in 1989 after squatting in the 'St[r]ung Hav Oil Refinery'. The land application receipts issued by the provincial land office were challenged by a group of CPAF-soldiers ${ }^{70}$ led by a major and several SOC police officers as well. The UN investigation unit commented:

'Although the CPAF has resorted to intimidation actions to reinforce its claims, these are criminal, and not political, in nature. It is neither possible, nor within our mandate, to decide on the validity of the various claims. The complainants are agreeable to our position, and are in the process of seeking a settlement through interdepartmental negotiation. ${ }^{71}$

This case, documented in detail by the UNTAC police unit 'CIVPOL Sihanoukville' outlines the mission's dilemma clearly: they could interfere only on the grounds of Cambodian law. While the formal procedure was correct - even though not necessarily fair and just - the hands of the CCC were, technically, tied. Claims to property before 1975 were not, in any case, eligible. The CCC was also unable to instigate an investigation without a formal complaint, which - it is assumed - left the majority of cases unreported. In the course of the mission, however, the CCC took on more and more of their own initiatives for further enquiries, while the SOC called upon UNTAC more often to decide on politically difficult cases and to act as moral enforcement of the government's own (eligible) claims.

\section{The caseload: a statistical overview for Cambodia and Phnom Penh}

\section{The Phnom Penh caseload: a qualitative investigation of the complaint files}

Tables 1 and $2 \mathrm{a}, \mathrm{b}$ and $\mathrm{c}$ give details of the complaints caseload. Two hundred out of 300 cases were analysed statistically ${ }^{72}$ by the author from three perspectives: (1) who filed the complaints, (2) what were the grounds for the appeal, and (3) was intimidation involved (and to what level did violence play a role)? Whereas some cases were reported as straightforward, clearly summarized and well presented,

69 NAC/UNTAC.BOX 3/1. Chamkarmon: 9.027 - Y. NEANG, Letter of complaint to UNTAC, addressed to Jesudas Bell (annex, 19 August 1992) HR/3-12/RP/35.

70 The Cambodian People's Armed Forces were renamed the former Kampuchean People's Revolutionary Armed Forces during the transitional times.

71 NAC/UNTAC.BOX 17/2. Sihanoukville - Groupe de plaignantes de Prek Treng, Investigation Papers IF/114/92, 19 December 1992.

72 Due to time constraints of the research project, this sample (two-thirds of the entire data for Phnom Penh), plus additional random sampling, has been deemed statistically sufficient. 


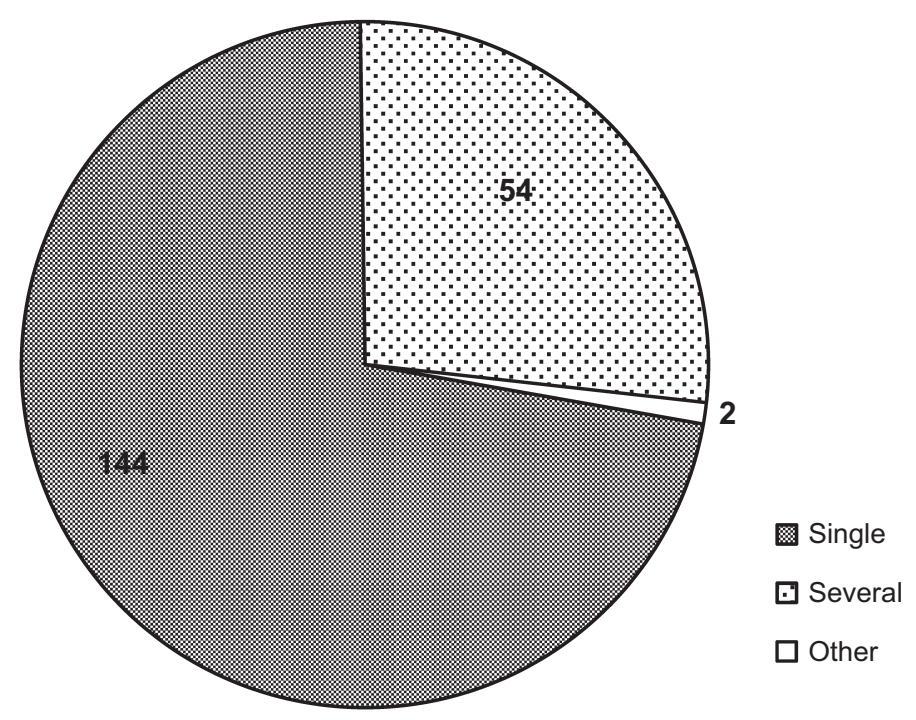

Figure 4a. Complainants $(\mathrm{n}=200)$.

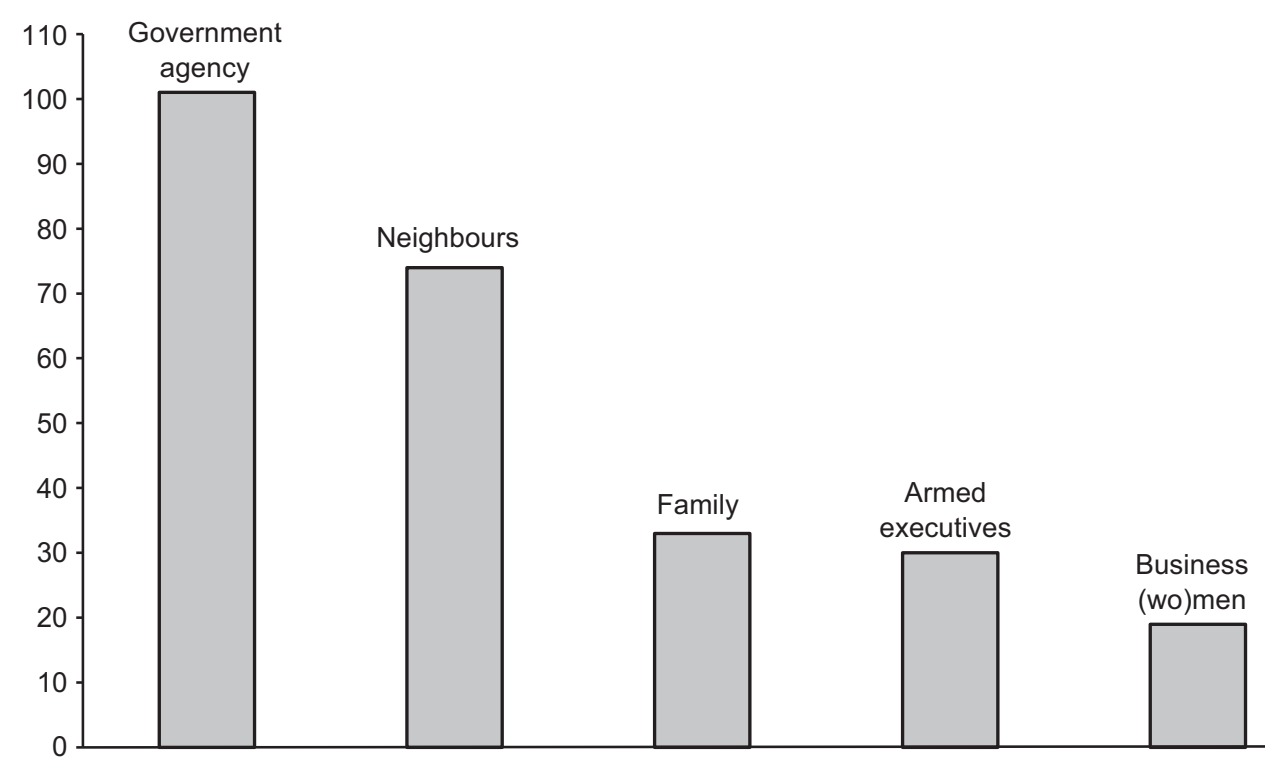

Figure 4b. Case leaders $(\mathrm{n}=200)$.

Note: A case may appear in more than one category.

Key to categories: Family: related persons and inmates/roommates (non-related or 'adopted' persons who did not pay rent); most members of these 'extended families' were more recent arrivals; some knew each other from work. They voluntarily shared one common living space. Neighbours: related or non-related persons living in adjacent but separated living space as a result of the physical division of former larger estates by order of PRK authority or by mutual agreement. Business (wo)men: private business people (with a few exceptions, Cambodians only). Government agency: public authorities and civil services of SOC at state, city, district or village level. Armed executives: military and police force, including officially demobilized and disarmed personnel. 


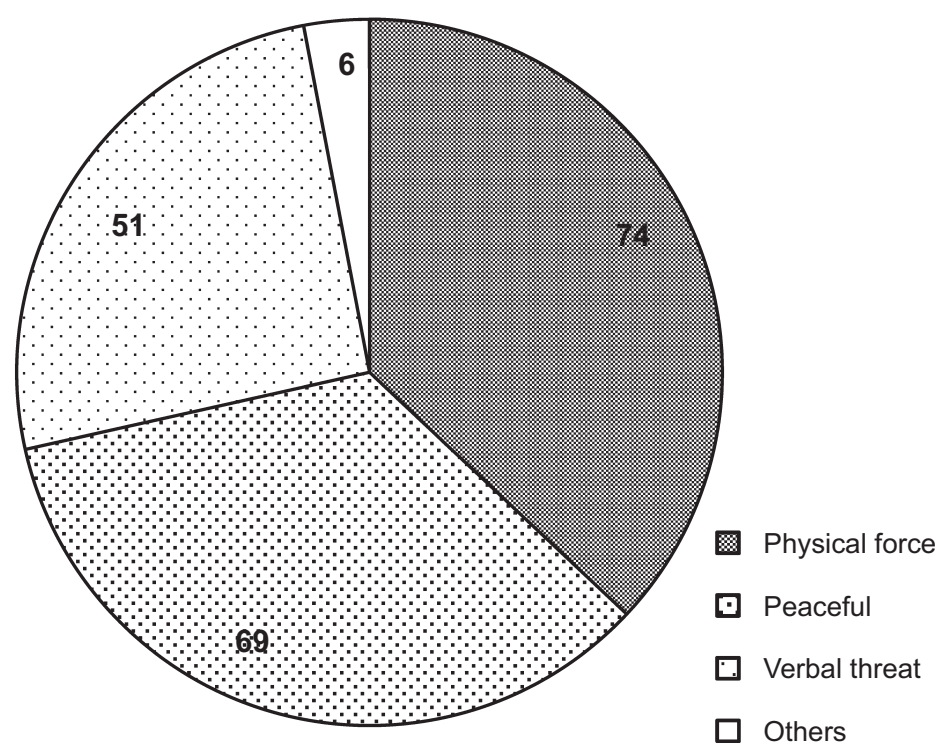

Figure 5a. Level of intimidation $(n=200)$.

Categories: Verbal threat of physical violence (without exercise of violence); use of physical force, acts of violence; peaceful (or no indication of intimidation involved); others (not specified, unknown).

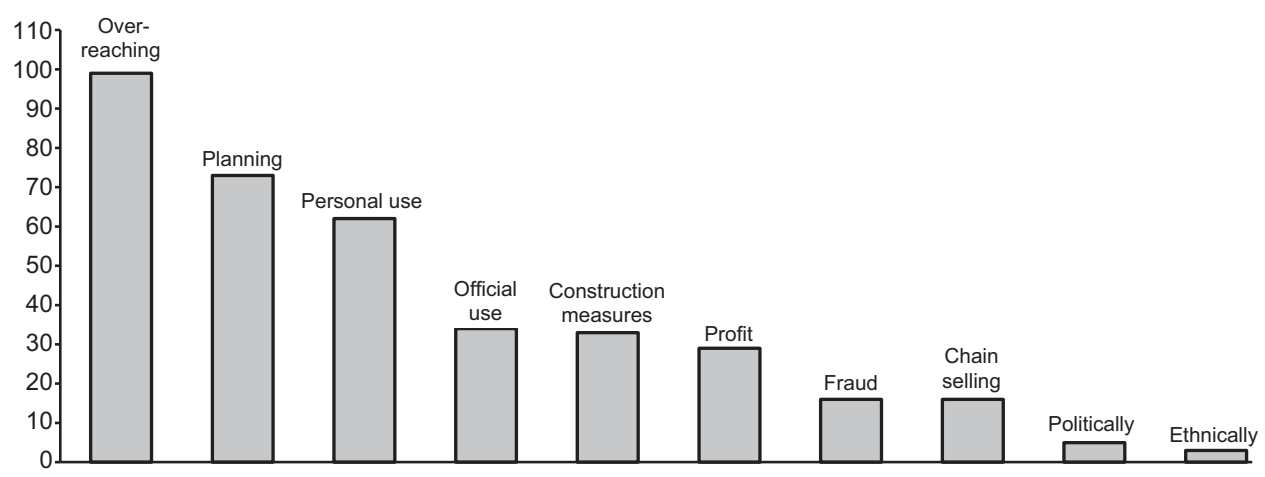

Figure 5b. Nature of complaints $(n=200)$.

Note: A case may appear in more than one category.

Key to categories: Overreaching: similar to fraud, but without an immediate threat of existence, such as taking improper advantage of people in distress, exploiting inexperience or credulity (for example, non-consensual sharing or splitting of living space or unilateral measures by authorities, including personal enrichment of individual officials) or breaking of previous practices (customs) in land affairs and property ownership. Official use: formally reasonable and justified property claim of SOC authorities (public demand) issued by private individuals. Planning: similar to official use related to city development. Personal use: justified or non-justified property claims of private individuals by other private individuals. Construction measures: construction work (maintenance, improvement and upgrading; new building or initial development; technical modification of public buildings or infrastructure). Profit: commercial purpose and profit-making. Fraud: intentional deception used for personal gain under false pretences or malicious concealment with or without exercise of violence, causing serious material or financial damage to the applicant (for example, evictions, full or partial expropriations with no or inadequate compensation). Chain selling: repeated informal transfer of (legally) unsecured tenancy and property rights, making any regress or steps against fraudulent transfer impossible. Politically motivated: harassment and financial/material damage for political reasons. Ethnically motivated: harassment and financial/material damage on grounds of race, nationality or ethnic background. 
comprising only a few pages, others were voluminous and difficult to disentangle. However, these latter cases especially provide a more profound insight into what was happening on the ground (see Figures $4 \mathrm{a} \& \mathrm{~b}$ and $5 \mathrm{a} \& \mathrm{~b}$ ).

At first glance, the high number of family and neighbourhood disputes is remarkable. To call them 'family dramas' is to underrate the seriousness of these conflicts, sometimes including murder, manslaughter and threatened suicide, the expulsion of even close relatives, the destruction of goods or the forceful occupation of living space. Residential property was usually at stake.

About the same number of complaints was brought forward by local authorities against private individuals: this spectrum ranges, on one hand, from accusations of arbitrary rule made against the SOC administration to complaints obviously motivated by bribes. On the other hand, it also includes complaints by the administration against individual citizens, which were filed with UNTAC on legal grounds.

The level of intimidation, which was a symptom of an 'extremely violent societyy $^{73}$ after 30 years of war, civil war and mass violence, is also striking. One serious failure of UNTAC was the unsuccessful disarming and decommissioning of the civil war troops, which left most of them in a precarious (economic) situation. Only fractions were transferred into the new armed forces of Cambodia. ${ }^{74}$ Armed forces, discharged or not, easily turned into gunmen. The UN was aware of a veritable market for private enforcement, which was termed 'rent-a-soldier'.$^{75}$

\section{The rush hour to enrichment: a 'secondary' accumulation of capital in Phnom Penh}

After the 'original accumulation' of political power during the resettlement process of Phnom Penh in the early 1980s, a second accumulation process began about 10 years later. The communist economic system was dismantled in favour of the principles of a free market economy in progress, and the early 1990s became a period of strategic exploitation and valorization for profitable reasons. All social strata became involved in the capitalization of landed property from the smallest up to the largest businesses. Five fields of activities can be identified: land grabbing, business, disloyalty of superiors, CPP nationalization and evictions

\section{Land grabbing for personal use}

I employ the term 'land grabbing' to point to the definitive end of the consensual way of sharing urban space. The term includes indoor 'room or flat grabbing'. Land and residential property, given the current transition of the political economy,

73 Defined by Christian Gerlach as 'formations where various population groups become victims of massive physical violence, in which, acting together with organs of the state, diverse social groups participate for multitude of reasons'; Christian Gerlach (2010), Extremely Violent Societies Mass Violence in the Twentieth-Century World, Cambridge UP, Cambridge, $\mathrm{p} 1$.

74 As late as March 1993, only 55,000 troops (out of 200,000) of the different factions had been relocated into 52 cantonment facilities. The disarmament programme was suspended since it was failing to achieve its purpose; Boradem Nhem (2011), A Continuation of Politics by Other Means: The "Politics" of a Peacekeeping Mission in Cambodia (1992-93), PKSOI Papers - Strategic Studies Institute, Carlisle, PA, pp 24. Peter Hazdra provides a detailed summary of the different armed forces of the civil war parties, Hazdra, supra note 58, at pp 53-58, 156-164.

75 For example, NAC/UNTAC.BOX 18/1. Phnom Penh. EVICTION CASES - Lau Kok ANG, Memo Lyndall McLean (Phnom Penh, Provincial HQ) to Eduardo Vetere (Acting Director, Public Security), 28 January 1993. 
became highly sought-after assets, especially in Phnom Penh. In the early 1990s the capital, in particular, was preparing for the foreseeable future of foreign capital investment, which also needed clear ownership status. The new inhabitants tried to convert their right of temporal use into full property rights by registering their lots and apartments. ${ }^{76}$ The CCC files bear witness to drastic disputes over smaller, even very small units that were the size of a toilet. However, even minor cases could provide a stage for the 'deep play' of political groups. In one legal conflict, for instance, Chea Sim and Hun Sen were each supporting one party in the land dispute over the amount of 520 chi of gold (about US\$2,000). Finally, they forwarded this stalemate case to UNTAC: the neutral UN should act as referee, at least in this case. ${ }^{77}$

\section{Rental, retail and real estate business}

The demand from UNTAC personnel, and later from NGOs, for living and office space clearly showed the potential of proper real estate in the capital city. 'Villas' could be rented out for thousands of US dollars, paid in advance, sometimes for years. ${ }^{78}$ The high 'expense allowances' of UNTAC also boosted the retail economy after a sharp decline in small business start-ups over the three years before the UN mission. ${ }^{79}$ In Phnom Penh, a veritable 'gold rush' broke out, although the streets were not 'paved with gold', but the right location along the street could offer a golden opportunity.

One speculator, for example, invested in a portfolio of gold, cement and beer. ${ }^{80}$ He left debts of three-quarters of a million US dollars to his Hong Kong-based creditors. At the time of his disappearance, 15 buildings were listed on the real estate register under both his and his wife's names. These included nine 'villas', most of which had 'probably' already been sold in the view of the office director of the cadastre. Evidently, the 'investor' belonged to the group of so-called 'wellconnected persons', as the legal representative of the overseas investor group noted with frustration:

'Mr. Dim Kim Sorn's attitude has clearly been displayed by his complete disregard for the legal system in Cambodia, by ignoring any invitation he has received by the court in the court's attempt to resolve the above case.' ${ }^{81}$

76 Interviews with real estate agents in Phnom Penh, 2011-12.

77 The case was classified by UNTAC as ' $x$ C': 'Complicated cases involving multiple selling of property, decisions of various administrative and judicial institutions (conflicting), including the Council of state and influence of both parties to authorities. We agreed with the Supreme Court, but the case was still not resolved definitively', NAC/UNTAC.BOX 3/2. Chamkarmon: 45.171 CHHAI POT.

78 Examples: NAC/UNTAC.BOX 18/2. Chamkarmon: OTHER CASES - Kong Nath, Protocol, 5 Dec 1993 monthly rent for a villa US $\$ 900$, three rents in advance, NAC/UNTAC.BOX 4/2. Chamkarmon: 61.229 - SOUTHEAST ASIAN OUTREACH, contract with 15 rents in advance; NAC/UNTAC.BOX 18/1. Phnom Penh. CYA/AN/AC/ER/PP/105 - KANN MAN, rent of US $\$ 1,000$, investment of the NGO for adaptation and extension estimated US\$25,000 (according to Maurits van Pelt, General Coordinator MSF - Médecins sans Frontières), Christiane Blancot states a range of rents between US $\$ 1,500$ to $\$ 10,000$ up to three years in advance: Christiane Blancot (1992), 'Phnom Penh - une ville-jardin à réglementer', Urbanisme, Vol 259, décembre, pp 76-79.

79 For a detailed investigation of Phnom Penh's retail business, see Kolnberger, supra note 39.

80 The shipping documents for Dim Kim Sorn stated, besides 13 kilos gold bars, 5,466 tons of Portland Cement, 478,000 cans of Heineken, and also 50 tons of 'raw Cashew Nuts'.

81 NAC/UNTAC.BOX 18/2. Chamkarmon: OTHER CASES, Affaire commerciale opposant M. Michel Seeger à M. Dim Kim Sorn, letter to the Phnom Penh tribunal, 1 March 1993; final sum of damage (according to correspondence, 25 March 1993: US\$585,763). 
Table 3. 'Official' one-time distribution key and profit quotas of the Ministry of Social Action.

\begin{tabular}{lr}
\hline Distribution key & US\$ \\
Level of minister \& vice-minster & 1,500 \\
Level of director \& deputy & 900 \\
Level of head of office & 500 \\
Level of staff \& workers & 400 \\
\hline
\end{tabular}

Source: NAC/UNTAC.BOX 18/1. CASES INVOLVING PROPERTIES

OF VARIOUS 'MINISTRIES', Ministry of Social Action (PP/JB/MO17,

11/03/1993) UNTAC Memo concerning sale of 'collective land'.

A further example is provided by the case of the 'Bopha Khlang Rumsev Restaurant Dancing'. This area in Phnom Penh's Tuol Kork had a building permit and licence for a 'cultural centre', which was transformed into a specific rendezvous site for male visitors with deep pockets. ${ }^{82}$ This north-western district of the city was 'patronized' by military and police personnel. When its informal landlords realized that the official rent and unofficial protection money were too low, they showed the tenant the door on the pretext of having breached a minor building code. Pacta [non] sunt servanda: the deceiver was deceived for the sake of higher profit rates, which were distributed amongst the protectors and their clientele.

\section{Disloyalty of superiors}

The UNTAC files brought several distribution keys and profit quotas to light (see Table 3). According to the rank within the administration, 'informal' revenues in cash were distributed amongst the members and clienteles of the 'cités'. In the early 1990s, 'selling off' state property caused a rush because the privatization of properties was going to foreclose this source of revenue in the future, which, to date, had been shared collectively.

Some disputes produced mutual allegations of greed and fraud. The opportunity for a last 'cash prize' was very tempting for superiors, who manipulated land distribution in their own favour, as the caricature of members of the Ministry of Culture denounces with hints of bitterness (see Figure 6).

Suspecting that they were being cheated, complainants blocked even reasonable deals: the 'underdogs' tried to take their chances too, as the statement of the Minister of Health - in my interpretation - shows credibly:

'The Ministry tried to convince them many times, trying to persuade them by economic settlement, to protect the interests of both sides, but, in this case, the Ministry was not successful. The reason is that these people are stubborn, they insist on having their own highest personal benefit, and are too greedy' ${ }^{83}$

The complainants - staff of Phnom Penh's Calmette Hospital - had settled on premises which attracted further squatters, but which had been earmarked for necessary construction work.

The atmosphere was poisoned by a prolonged state of impending insecurity - a

82 Prostitution, particularly prostitution of destitute women of Vietnamese and Cambodian families, became a mass phenomenon during UNTAC.

83 NAC/UNTAC.BOX 1/2. Daun Penh: 42.248 - CALMETTE HOSPITAL, letter of the Ministry of Health to UNTAC, 30 September 1992, signed by the chief of staff. 


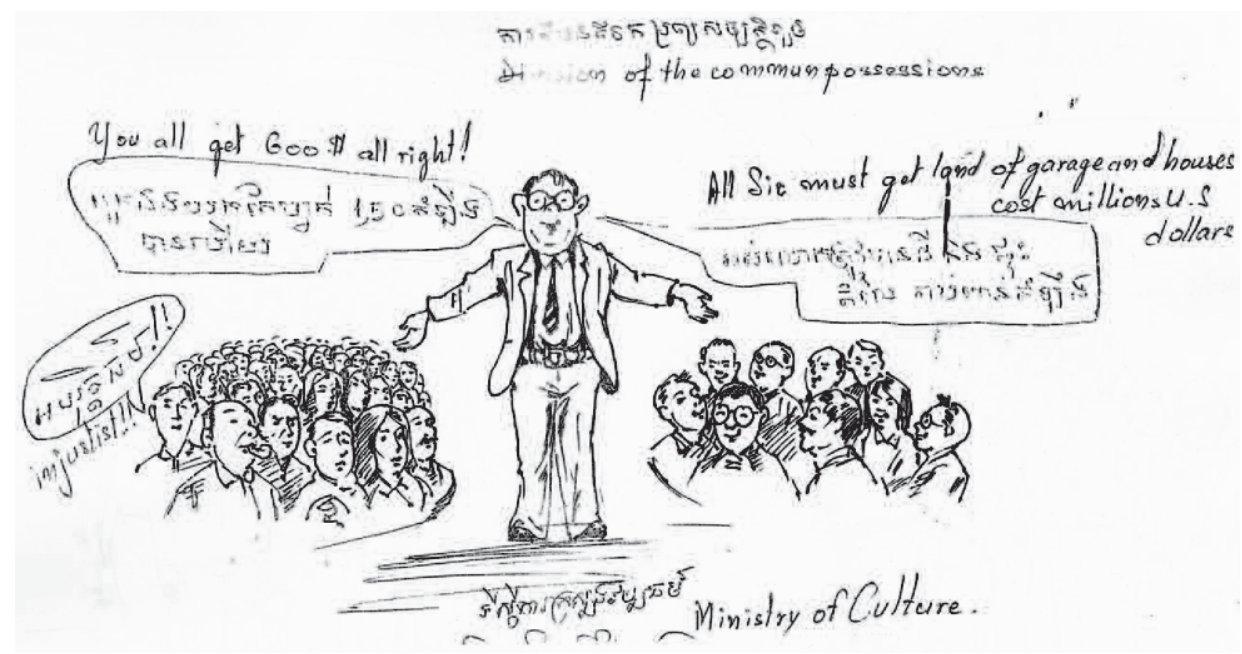

Figure 6. Disloyal pocketing? The minister in a dubious light. The twilight of a system produced winners, the lucky few on the right, and losers, the unfortunate many on the left of the sketch, with the minister as arbitrator of fortune in the middle.

Source: NAC/UNTAC.BOX 18/1. Phnom Penh. SS/HSS/AC/PP97, Ministry of Culture Staff;

English translation added by UNTAC staff.

situation which was aggravated by the decision of Cambodia's state council turning state property into party property.

\section{CPP nationalization}

In 1993, the 'Cambodian People's Party' (CPP), the direct successor of the Communist Party, legitimized its property and assets. According to a decree of the State Council of Cambodia (Law of the Assignment of Properties), signed by Heng Samrin, all movable and immovable properties controlled by the CPP prior to 1993 were to be considered the Party's exclusive possessions:

'The State of Cambodia and the Cambodian People's Party shall make inventories of their respective properties as of the dates this law came into force (Article $5) .{ }^{84}$

De facto, this decision made the CPP into another 'state party' of Cambodia, granting it more superior resources than the competing parties. Party members were to secure (to 'inventory') the claims and were supposed to help to assert their 'right', even with force, when necessary. Phnom Penh experienced a first wave of evictions and confiscations.

\section{The first wave of evictions}

The Committee for the Establishment of Social Oder and Security for the Capital had conducted earlier evictions in the late 1980s: Chinese 'capitalists', first and

84 The decision was discussed by the UN; see NAC/UNTAC.BOX 18/1. POLICIES/GUIDELINES - UNTAC, UNTAC Memo, especially the comments of 31 March 1993. 
foremost, and small businessmen had been deported ${ }^{85}$ It is also a known fact that hundreds of Cambodian families fell victim to power plays of the elites in the early PRK years and were forced out of the city. ${ }^{86}$

Individuals or groups of people with good connections, however, rarely became victims of evictions. The inhabitants of the Wat Prayouvong, south-east of the Independence Monument, for example, could prolong their technically illegal land occupation of large parts of the temple. The first consensual resettlement arranged by PRK authorities prevailed against legal claims of the Buddhist monks. Even in 2009, the 'informal settlers' did not receive a land title, which could have resulted in immediate eviction. However, in 2015 the temple ground was still being squatted on, also thanks to political influence. ${ }^{87}$

Besides patronage, location constituted a second factor in being prone to displacement. Without an immediate investment project, 'informal settlers' along Phnom Penh's railway track bed could keep their overnight 'constructions anarchiques' until the $2010 \mathrm{~s} .{ }^{88}$ For others, the SOC-CPP administration coined two frequently used expressions of 1992-93: 'anarchy' and 'illegal occupant/ squatter'. Many disputes were clear cases of forceful and unwarranted evictions. Others demonstrated the ambiguity of this period, when some tried to seize the opportunity to claim their share, as in the dispute over a new embassy building. Thai authorities, trying to de-escalate the situation, were simply blackmailed. They were required to pay compensation of US $\$ 900$ for very basic huts, set up by squatters on the construction site. Immediately after the settlement, some of the paid-off settlers set up new huts on the border of the lot, again on public ground.$^{89}$

It is not sufficient to define the situation as one of a dichotomy between perpetrators and victims, as the case of the so-called 'casino zone' at the river front of the Chaktomuk (close to the Cambodiana Hotel) clearly demonstrates. In 198485, 60 families settled there in 53 houses. In June 1992, 241 families were on the site, and this figure rose steeply when the news of compensation spread. In July, 1,042 houses were either completed, occupied or under construction. It is known that there were at least 14 police families and 26 military families present. The number of Vietnamese families was at least $200 .{ }^{90}$ In total, 36,000 people were evicted by Cambodian authorities, some of whom received compensation, some

85 Under Pol Pot, even the massive assistance of the PR of China did not prevent the persecution of Sino-Khmers or ethnic Chinese by the PRK. However, the hyper-nationalistic Khmer Rouge rule targeted its 'historical arch-enemy', the Vietnamese. Khmer ethno-chauvinism, discriminating against Chinese Cambodians and Vietnamese, continued under the new regime until the beginning of the change from a socialist to a market economy in the late 1980s; cf CAS (Center for Advanced Studies) (2009), Ethnic Groups in Cambodia (coordinated by Hean Sokhom), CAS, Phnom Penh, especially chapter 2 (Ethnic Chinese in Cambodia, by Penny Edwards) and chapter 5 (Les Viêtnamiens au Cambodge, by Didier Bertrand).

86 Gottesman, supra note 8, at pp 179-182.

87 NAC/UNTAC.BOX 18/1. EVICTION CASES, Civpol District 1 Phnom Penh, 92/92/AU Proyovong Pagoda; originally, 700 families were registered there; interview with Bridges across Borders (BABC) and inhabitants, January 2012.

88 NAC/UNTAC.BOX 18/2. Tuol Kork: EVICTION CASES, Letter of the People's Committee/ Comité Populaire, N. 1005 to chief of district, Toul Kork, concerning Mr. Koy Ny, 29 March 1992.

89 NAC/UNTAC.BOX 3/1. Chamkarmon: 16.064 - SAO HUTH and numerous (New) Thai Embassy; NAC/UNTAC.Box 1/1.Daun Penh: 25.176 - PRAK CHANNY \& PRAK CHANDA, Notification, 30 July 1993 for house 429 EO, street 310.

90 NAC/UNTAC.BOX 18/1. EVICTION CASES, Casino zone; according to an UNTAC survey. 
of whom became victims of unjust treatment, and others for whom micro-speculation did not pay off. ${ }^{91}$

\section{Conclusions}

Reas mean mun rodth is the leitmotif of Hun Sen's economic pragmatism: 'the people become rich before the state' ${ }^{92}$ In fact, when the capital was repopulated after 1979, the people of Phnom Penh were not given 'riches', but those who were allowed in were offered security and subsistence. Some of them - the entourage of the political elites - received privileges; others were sheltered on the leeward side of this initial face-to-face state-building during the 1980s. The original accumulation of political power was followed by a first 'pay day': the privatization of property and profits of collective resources in the early $1990 \mathrm{~s}$, separating the wheat from the chaff in terms of political connections. Cambodians were initially reluctant to accumulate wealth in a conspicuous form - now the time had arrived to do so. In this phase of reconciliation, the SOC/CPP leaders had to tolerate a 'free play of personal interests', which they needed in order to establish a delicate balance of power within the new party. This social and economic capital was invested in what Caroline Hughes calls a 'follower democracy'. ${ }^{93}$

The paradox of the new situation is that Hun Sen and the CPP have not been popular with the majority of urban citizens of Cambodia ever since, particularly in Phnom Penh, whose electorate votes consistently for the opposition. Close contact with a handful of economic-political protagonists, however, proved to be sufficient for this new type of leadership. The resulting nexus of money and political influence has even been sealed by strategic marriages of the economic and state elites. ${ }^{94}$ Political power in Phnom Penh has never represented the population of the countryside, and the capital has remained a playground for elites. The (popular) power base of the CPP then shifted to the provinces, where its funds, accumulated during the civil war, were invested in permanent electoral campaigns. ${ }^{95}$

UNTAC was definitely a catalyst for this development, but not the cause, as the above analysis of its files has shown. UNTAC never governed Cambodia - its mission would probably have been a failure, had it tried to do so. Where the mission succeeded, however, was in the repatriation of war refugees and internally displaced Cambodians, the start of the mine-sweeping campaign, the national elections, conducted with only minor violence, and the formation of a new government as a result. Obviously, the patronage system governing Cambodia was the price to be paid for stability.

91 Ibid.

92 Margaret Slocomb (2006), 'The nature and role of ideology in the modern Cambodian state', Journal of Southeast Asian Studies, Vol 37, p 394.

93 Hughes, supra note 10, at p 5.

94 See: 'It's a Family Affair', Phnom Penh Post, Weekend supplement, 23 February-8 March 2007, p 8.

95 These funds consisted of money and man-hours poured into intensive political campaigning; cf COMFREL (Committee for Free and Fair Elections in Cambodia); and 'CPP tailors its tactics to rural voters', The Cambodian Daily, 28 Nov 2011, p 1. 


\section{Appendix Demographic development of Phnom Penh, 1975-92}

\begin{tabular}{lcc}
\hline Table A1. Population of Phnom Penh, 1975-92. & \\
\hline Year & Version A & Version B \\
1975 & $1,800,000^{\mathrm{a}}$ & $2,000,000^{\mathrm{b}}$ \\
$1976-78$ & $20,000^{\mathrm{c}}$ & $100,000-125,000^{\mathrm{d}}$ \\
1979 & $30,000^{\mathrm{e}}$ & $122,779^{\mathrm{f}}$ \\
1980 & $299,800^{\mathrm{g}}$ & $320,000^{\mathrm{h}}$ \\
1982 & $390,315^{\mathrm{i}}$ & - \\
1984 & $423,162^{\mathrm{j}}$ & - \\
1987 & $584,000^{\mathrm{k}}$ & - \\
1992 & $667,814^{1}$ & $674,509^{\mathrm{m}}$ \\
\hline
\end{tabular}

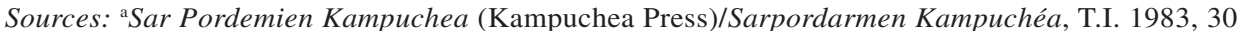
janvier; cf Carrier, supra note 11, at p 125; bJacques Migozzi (1973), Cambodge, faits et problème de population, CNRS, Paris ; cf Vann Molyvann (2003), Modern Khmer Cities, Reyum, Phnom Penh, p 22 (estimation of UNICEF). 'Valérie Deletage (2006), 'Phnom Penh, renaissance d'une capital sacrifiée', PhD dissertation, Geography, University of Bordeaux III, p 87. 'Marie-Alexandrine Martin (1983), 'L'industrie dans le Kampuchéa démocratique (1975-1978)', Études rurales 89-90 (L'Asie du Sud-Est entre la Chine et l'Inde Agriculture et pouvoirs), Vol Jan-Sep, pp 77110 (p 87). ${ }^{\circledR}$ Evolution démographique de Phnom Penh (1962-2003) BAU/INS; cf Comité populaire révolutionnaire de Phnom Penh: Recueil de données statistiques 1979-1992. ${ }^{\mathrm{f}}$ Comité populaire révolutionnaire de Phnom Penh: Recueil de données statistiques 1979-1992 for Dec 1979. ${ }^{\mathrm{g}} \mathrm{Ibid}$. ' $E v$ volution démographique de Phnom Penh (1962-2003) BAU/INS. 'Deletage (2006), supra source (c), at p 87. ${ }^{\mathrm{j} D e l e t a g e}$ (2006), supra source (c), at p 87. ${ }^{\mathrm{K}} \mathrm{UNDP}$ (Kampuchea Needs Assessment Study), August 1989, according to: Molyvann (2003), supra source (b), at p 22.

'UNCHS (Needs Assessment Mission), May 1992, according to: Molyvann (2003), supra source (b), at p 2. ${ }^{\mathrm{m}} \mathrm{UNTAC}$, cf Deletage (2006), supra source (c), at p 85. 